\title{
Integrating glaciers raster-based modelling in large catchments hydrological balance: the Rhone case study
}

\author{
L. Boscarello, ${ }^{1 *}$ G. Ravazzani, ${ }^{1}$ D. Rabuffetti ${ }^{2}$ and M. Mancini ${ }^{1}$ \\ ${ }^{1}$ DIIAR-CIMI Politecnico di Milano, Italy \\ ${ }^{2}$ Regional Environment Protection Agency - ARPA Piemonte, Italy
}

\begin{abstract}
:
A raster-based glacier sub-model was successfully introduced in the distributed hydrological model FEST-WB to simulate the water balance and surface runoff of large Alpine catchments. The glacier model is based on temperature-index approach for melt, on linear reservoir for melt water propagation into the ice and on mass balance for accumulation; the initialization of the volume of ice on the basin was based on a formulation depending on surface topography. The model was first tested on a sub-basin of the Rhone basin (Switzerland), which is for $62 \%$ glaciated; the calibration and validation were based on comparison between simulated and observed discharge from 1999 to 2008. The model proved to be suitable to simulate the typical discharge seasonality of a heavily glaciated basin. The performance of the model was also tested by simulating discharge in the whole Swiss Rhone basin, in which glaciers contribution is not negligible, in fact, in summer, about the $40 \%$ of the discharge is due to glacier melt. The model allowed to take into account the volume of water coming from glaciers melt and its simple structure is suitable for analysis of the effects of climate change on hydrological regime of high mountain basins, with available meteorological forcing from current RCM. Copyright (C) 2012 John Wiley \& Sons, Ltd.
\end{abstract}

KEY WORDS distributed hydrological modelling; large catchment; glaciers mass balance; alps

Received 22 December 2011; Accepted 8 October 2012

\section{INTRODUCTION}

Alpine environments, as the Swiss Rhone, are strongly influenced by the presence of glaciers. Glaciers store water as snow and ice in winter and release it in summer; this causes seasonal and diurnal discharge variations significantly differing from those of conventional landscapes (Hock, 2003). Runoff of Alpine catchments is strongly dependent from altitude and during melt season snow and glacier melt contribute significantly to the total discharge (Verbunt et al., 2003; Milner et al., 2009).

Several approaches exist to model glaciers within hydrological models, as well as different methods exist to simulate melt and accumulation of ice.

Concerning the modelling of glaciers, there are in general two kinds of model: conceptual hydrological models and physically based models. The first, (Klok et al., 2001; Verbunt et al., 2003; Schaefli et al., 2005), are applied in small glacierized basins, where they perform well and glaciers processes can be detailed reproduced; the second, (Huss et al., 2008; Farinotti et al., 2009a, b), can reproduce accurately glaciers volume changes and mass balance in well monitored and relative small catchments, since they require lots of data input and onerous calculation.

Ice melt models can be grouped in two main categories: energy balance and temperature-index models (Hock, 2003);

*Correspondence to: Laura Boscarello, DIIAR-CIMI Politecnico di Milano, Italy.

E-mail: laura.boscarello@mail.polimi.it the first type of models has a strong physical basis because each of the relevant energy fluxes at the glacier surface is computed using direct measurement of meteorological variables and thus allows to obtain melt rates with high precision and with high temporal resolution; in the second type of models, melt rate is calculated from empirical formulas. However, despite the simplicity of the temperature-index models, they are commonly used because of wide availability of temperature data and lower computational cost; furthermore, Hock (Hock, 2003) highlighted the physical basis of such kind of models. In a typical temperature-index model, melt rates are simulated at daily or coarser spatial resolution; nevertheless, extended formulations have been analyzed (Hock, 2003; Pellicciotti et al., 2005): the introduction of incoming radiation and the separation of temperature-dependent and independent energy sources can significantly improve melt rate simulations, allowing to take into account diurnal fluctuations.

In more detailed models, accumulation is modelled taking into account snow, firn and ice and the spatial redistribution of snow due to drift and avalanches (Huss et al., 2008); in conceptual models, accumulation of ice is not often taken into account because they typically starts from an infinite volume of ice or consider glaciers area constant in time (Klok et al., 2001); otherwise, they solve mass balance between solid precipitation, snow melt and glacier melt (Schaefli et al., 2005; Horton et al., 2006; Konz and Seibert, 2010).

It is also well known that melt water coming from glaciers is the result of energy and mass balance, but the ways and the times in which water reaches the front of the 
glacier are difficult to model because they depend on the drainage system of the glacier, usually composed by interconnected sinkholes and underground tunnels in which water flows rapidly. (Noldin et al., 2010); so, modelling the englacial drainage system explicitly is hard; therefore, the concept of linear reservoir is frequently applied (Klok et al., 2001; Verbunt et al., 2003; Schaefli et al., 2005).

In the last years, several studies have focused on the contribution of glaciers to runoff in large catchments (Kaser et al., 2010; Huss, 2011; Jost et al., 2012). Among them, Jost et al., 2012 and Huss, 2011 studied the contribution of glaciers within a hydrological model, while Kaser et al., 2010 studied the contribution potential of glaciers into different large river basin all over the world by using monthly mean values of temperature and precipitation and glaciers data from World Glacier Inventory. Huss, 2011 used a distributed hydrological model and mass balance data of 50 Swiss glaciers and extrapolated storage changes to all glaciers in European Alps to study present and future contribution of glacier in four different big streams: Rhine, Rhone, Po and Danube; he found that the relative importance of glacier contribution to runoff does not scale linearly with the percentage of glacierization and that glacier melt waters have impact not only at a regional scale, but also on the hydrological regime of macro-scale watershed. In Jost et al., 2012, they use a semi-distributed hydrological model applied to the Mica basin of $20742 \mathrm{~km}^{2}$ and only $5 \%$ glaciated. By using known glacier volume and area changes to constrain the calibration of the model, they found that glaciers contribute up to $35 \%$ of summer streamflow and that the sensitivity of streamflow to historic glacier area changes is small, but glaciers area need to be updated when the model runs for future projections.

The purpose of this study is to introduce a module to model glaciers in large catchments, within the distributed physically based hydrological model FEST-WB (Montaldo et al., 2007; Rabuffetti et al., 2008; Corbari et al., 2011). Estimating the contribution of glacier melt to runoff for large basins is surely a challenge because hydrological models use coarse resolution to model the water mass balance, while modelling glaciers requires high resolution and detailed input data. We try to overcome these difficulties by building a model simple in structure but without losing the rasterbased approach of the whole model. The glacier model requires few input data (glaciers area, digital elevation model (DEM), temperature and precipitation) and is able to reproduce melting, with a simple temperature-index melt model, accumulation and propagation of melt water into ice, with a linear reservoir method. The raster-based approach of the model allows to take into account variations in glaciers area and thickness according to annual mass balance. Obviously, glaciers area changes are rough because affected by inaccuracies due to the low DEM resolution and to the simplicity of the model that does not take into account glaciers flow and dynamic (Johannesson, 1997; Oerlemans, 1997; Oerlemans et al., 1998). Nevertheless, area changes will be relevant, as stated in Jost et al., 2012, when the model runs with future climatic scenario, so one benefit of this module is the possibility of computing glaciers area changes. Furthermore, the purpose of the hydrological model is to estimate future contribution of glacier melt to runoff under condition of a changing climate, so the model needs to start from a reasonable volume of ice on the basin. The simple structure of the model is necessary for several reasons: (i), the scarcity of meteorological data both from quantity and typology point of view (it is quite unusual finding measures of radiation or wind at high altitudes) and glacier's data in Alpine environments (Hock, 1999; Schaefli et al., 2005; Farinotti et al., 2009a, b); (ii), for analysis of the effects of climate change on hydrological regimes of Alpine basins, where available meteorological forcing from current RCMs (Regional Climate Models) generally include only precipitation and temperature; (iii), evaluation of the volume of water available in the basin in the present and in the future: neglecting glaciers contribution is inadmissible, but at the same time, we are not interested in reproducing accurately diurnal fluctuations of discharge caused by snow and glacier melt and glaciers area changes, that a coarse spatial resolution obviously does not allow to simulate.

In recent literature (Schaefli et al., 2005; Koboltschnig et al., 2008; Finger et al., 2011; Schaefli and Huss, 2011), improvements in calibration performed combining multiple data set to constrain model parameters have been shown. However, even if it is well known that snow and glaciers dynamic are intrinsically linked, in some studies (Klok et al., 2001; Verbunt et al., 2003; Verbunt et al., 2006) the parameters of glacier and snow are calibrated together by comparing simulation with only one data set, typically discharge data or ice mass balance gradient.

In this study, we separated calibration of snow model and of glacier model by using two different data sets, so to reduce calibration uncertainty, in fact, an accurate simulation of snow melt and accumulation and of snow cover area is crucial to ensure a proper simulation of covered and exposed iced areas. Snow accumulation model is calibrated and validated by comparison with satellite maps of snow cover. Glacier melt model is calibrated and validated by comparing simulated and observed discharge in a sub-basin which is almost completely glacierized, and then the performance of the calibrated model is evaluated on the whole basin.

\section{CASE STUDY AND DATA DESCRIPTION}

The basin under study is the Rhone catchment closed at Port du Scex, its input into Geneva's lake (Figure 1). The considered basin has an area of $5300 \mathrm{~km}^{2}$, and it presents typical alpine topography with an average altitude of $2082 \mathrm{~m}$; the percentage of ice cover is about $12 \%$. The hydrological regime is strongly influenced by glacier and snow melt: it presents the maximum discharge in summer months and the minimum in winter months, and the mean runoff coefficient is, for the period from 1999 to 2008 , equal to 1.22 . 


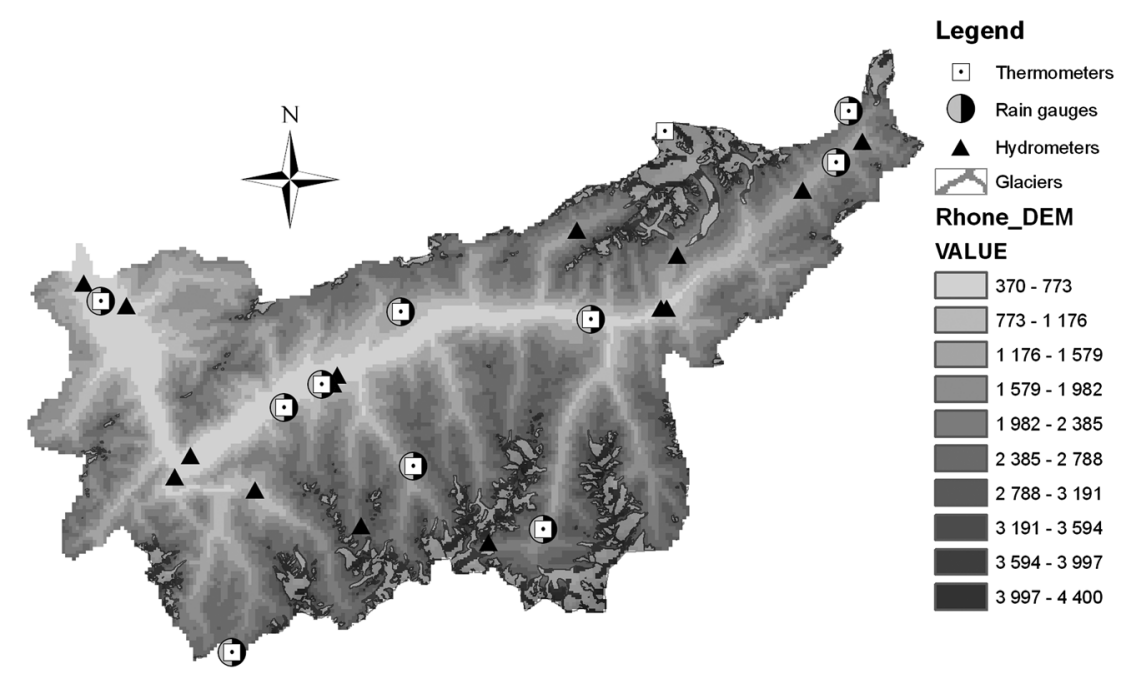

Figure 1. The Rhone watershed extracted from the digital elevation model, showing location of rain gauges, thermometers of air temperature measurements, hydrometric stations and location of glaciers

\section{Physiographic basin characterization}

For this study, the available digital cartographic data are: the DEM in raster format with a spatial resolution of $500 \mathrm{~m} \times 500 \mathrm{~m}$; CORINE land cover map (Rabuffetti et al., 2008) updated in the year 1990; a raster map with the types of soil present on the basin with associated values of permeability and active soil depth for each type of soil. From these available layers, basin's parameters necessary for the application of the model have been derived with a spatial resolution of $500 \mathrm{~m} \times 500 \mathrm{~m}$; these include: flow direction, Curve Number (Soil Conservation Service, U. S., 1986), residual and saturated soil moisture, albedo, pore size distribution index, saturated hydraulic conductivity, wilting point, field capacity, soil depth and vegetation fraction.

\section{Hydrological and meteorological data}

In the studied basin, 15 hydrometric observation stations are present. The data, collected by $B A F U$ (Federal Office for the Environment - http://www.bafu.admin.ch/hydrologie/ index.html?lang=de), are available from 1 January 1990 to 31 December 2008 with a temporal resolution of $1 \mathrm{~h}$. Only two stations were used: the Port du Scex and the Blatten Naters gauging stations.

Concerning the meteorological data, 11 stations, managed by MeteoSwiss, provide air temperature at $2 \mathrm{~m}$ above the ground, and ten stations provide rainfall at hourly time step from 1 January 1990 to 31 December 2008.

\section{Snow data}

Maps of snow cover are available from 26 February 2000 to 31 December 2008. These are satellite images coming from MODIS instrument aboard the TERRA and AQUA satellites (http://modis.gsfc.nasa.gov/index.php). Among the many products coming from MODIS, the 8-day snow cover product, MOD10A2, has been used. This product provides raster maps, with a spatial resolution of $500 \mathrm{~m} \times 500 \mathrm{~m}$, in which in each pixel the value indicates if the pixel is covered by snow or not, or if it is covered by clouds.
The MODIS maps have been validated by comparison with nine stations of ground data (Pellegrini, 2011). In few words, the steps for validation of data are the following: first, ground data were classified in a binary way as snow, no snow or nodata; second, MODIS data were also classified in binary way including in nodata pixel classified as clouds; third, all the days in which ground data or MODIS data or both have nodata were eliminated. After this step remains the $40 \%$ of the total amount of beginning data. With this amount of comparable days, contingency tables were calculated. The result revealed the $95 \%$ of agreement between MODIS and ground data that is comparable with the $94.7 \%$ obtained by Parajka and Blöschl, 2006 in which they apply the same methodology for MODIS snow cover images of Austria.

\section{Glacier data}

Concerning glaciers, the shapefile coming from the GLIMS project (Global Land Ice Measurements from Space, is a project designed to monitor the world's glaciers primarily using data from optical satellite instruments, such as ASTER - http://www.glims.org/) with the world glacier mapping referred to year 1999 is available. The shapefile contains information about the areal extent of each glacier of the basin. The area covered by glaciers in the studied basin is about $620 \mathrm{~km}^{2}$. For model elaboration, it is necessary to convert the shapefile in a raster file with spatial resolution of $500 \mathrm{~m} \times 500 \mathrm{~m}$.

\section{METHODS}

\section{The hydrological model FEST-EWB}

The hydrological simulations are performed using the FEST-WB distributed water balance model (Montaldo et al., 2007; Rabuffetti et al., 2008; Corbari et al., 2011) This model allows to calculate the main processes of the hydrological balance: evapotranspiration, infiltration, surface runoff, flow routing, subsurface flow and snow dynamics. In this study, 
the module to simulate the glacier dynamic was introduced. The firn dynamic is not taken into account.

In Figure 2, a scheme of the model is shown.

The computational domain is discretized by a mesh of squared cell, of $500 \mathrm{~m}$ per side, in each of which water fluxes are calculated at hourly time step.

The model needs spatially distributed forcing as input: precipitation, air temperature and the maps with the physiographic characteristics of the basin. The observed data at ground station are interpolated to a regular grid using the inverse distance weighting technique.

The evapotranspiration is calculated with the Hargreaves equation (Hargreaves and Samani, 1985; Ravazzani et al., 2012), which needs only temperature data as input.

Runoff is computed for each cell according to a modified SCS-CN method extended for continuous simulations (Ravazzani et al., 2007).

The surface flow routing, for the cell free from snow and ice, is computed with the Muskingum-Cunge method in its non-linear form with time variable celerity (Montaldo et al., 2007). Subsurface flow routing is computed with a linear reservoir routing scheme (Ponce, 1989) with a celerity calculated as a function of the soil saturated conductivity.

The snow module includes snow melt, accumulation and propagation into the snow pack; the melt model is based on a simple degree day depending on air temperature according to Equation (1); the accumulation model, Equations (2) and (3), provides the partitioning of total precipitation in liquid and solid by using two threshold of temperature, $\mathrm{T}_{\mathrm{LOW}}$ and $\mathrm{T}_{\mathrm{UP}}$, below/above which all precipitation falls as snow/rain and they have to be found with calibration; melted water is supposed to flow into the snow pack with a linear reservoir routing scheme. All the parameters of the snow model, the melt

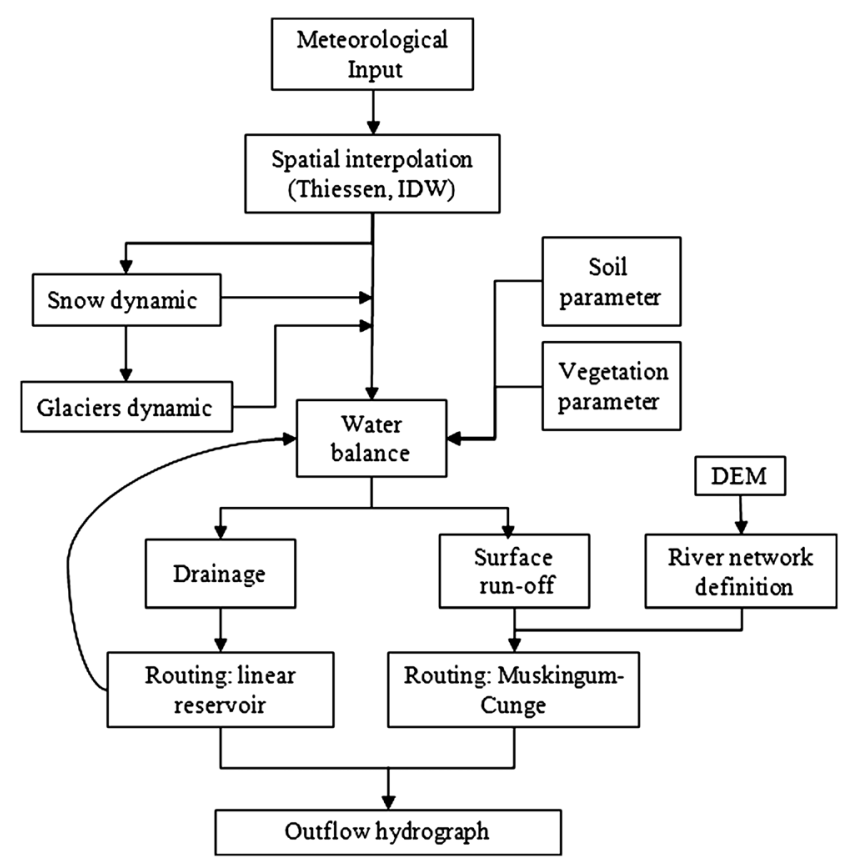

Figure 2. Scheme of the hydrological model FEST-WB factor and the two thresholds for accumulation, do not vary in time and space but are fixed values for the catchment.

$$
\begin{gathered}
M_{\text {snow }}=C_{m, \text { snow }}\left(T_{a}-T_{b, \text { snow }}\right) \\
\left\{\begin{array}{l}
P_{l}=\alpha_{P} P \\
P_{s}=\left(1-\alpha_{P}\right) P
\end{array}\right. \\
\left\{\begin{array}{c}
\alpha_{P}=0 T_{A}<T_{L O W} \\
\alpha_{P}=\frac{T_{A}-T_{L O W}}{T_{U P}-T_{L O W}} \\
\alpha_{P}=1 T_{A} \geq T_{U P}
\end{array} T_{L O W} \leq T_{A} \leq T_{U P}\right.
\end{gathered}
$$

Where $M_{\text {snow }}$ is the melt rate $[\mathrm{m} / \mathrm{s}], C_{m, \text { snow }}$ is the melt coefficient $\left[\mathrm{m} /{ }^{\circ} \mathrm{C} \cdot \mathrm{s}\right], T_{a}$ the air temperature $\left[{ }^{\circ} \mathrm{C}\right]$ and $T_{b, \text { snow }}$ is the threshold temperature behind which snow melt does not occur, typically equal to $0^{\circ} \mathrm{C} . P_{l}$ is the liquid fraction of total precipitation $P$ and $P_{s}$ is the solid fraction.

In the following, the glacier dynamic model is presented in detail.

\section{The raster-based glacier dynamic model}

For hydrologic analysis in this catchment is fundamental the introduction of glaciers mass balance because of their great presence in the basin, which produce most of water supply during summer. Glaciers are known to have a significant impact on stream flow runoff: they store water during winter season, while, during summer, melt water may provide the only source of water for some Alpine valley; they therefore play an important role on the river flow regimes with peaks of melting during the middle-late summer (Hock et al., 2005; Milner et al., 2009). It is well known that the structure and space-time dynamic of a glacier is very complex and representing it within a hydrological model applied to a large basin is surely a challenge on one hand because of data input, on the other hand because of the different spatial resolution required by glacier and hydrological models (Huss et al., 2008).

The glacier model introduced in the present study tries to overcome this difficulties. Even though respecting the raster-based approach of the whole structure of the FESTWB, so that glaciers area and volume changes can be calculated, the glacier model is sufficiently simple to simulate catchments of big dimensions, with data scarcity and that can be used for climatic change impact studies, whose input will be only temperature and precipitation.

With the purpose of simulating accumulation and melting of ice in a river basin, it is necessary to start with an initial condition which requires knowledge of the extent of ice on the basin and of the thickness of ice in each cell. This content is fully described in section 3.3.

The accumulation model for the glaciers is based on annual mass balance (Horton et al., 2006; Huss et al., 2008): it is determined by comparing the solid precipitation accumulated and the amount of snow and ice melted by the end of the hydrological year (September $1^{\text {st }}$ ). Hence, the volume of snow that has not melted by September $1^{\text {st }}$, is converted into ice. 
The ice melt model is based on the degree-day concept (Hock, 2003; Hock et al., 2005; Schaefli et al., 2005; Konz and Seibert, 2010; Schaefli and Huss, 2011) in which the melt rate is directly proportional to air temperature through a coefficient to be determined with calibration, Equation (4):

$$
M_{i c e}=C_{i c e}\left(T_{a}-T_{b, i c e}\right)
$$

where $\mathrm{M}_{\text {ice }}$ is the melt rate $[\mathrm{m} / \mathrm{s}], \mathrm{C}_{\text {ice }}$ the melt coefficient $\left[\mathrm{m} /{ }^{\circ} \mathrm{C} \cdot \mathrm{s}\right], \mathrm{T}_{\mathrm{a}}$ the air temperature $\left[{ }^{\circ} \mathrm{C}\right]$ and $\mathrm{T}_{\mathrm{b} \text {,ice }}$ is the threshold temperature behind which ice melt does not occur, typically equal to $0^{\circ} \mathrm{C}$.

The values of $C_{\text {ice }}$ vary from a minimum of $5.79 \cdot 10^{-8} \mathrm{~m} /{ }^{\circ} \mathrm{C} \cdot \mathrm{s}$ to a maximum of $2.31 \cdot 10^{-7} \mathrm{~m} /{ }^{\circ} \mathrm{C} \cdot \mathrm{s}$ (Schaefli et al., 2005). It is assumed that ice does not melt if its surface is covered by snow.

We decided to use a simple degree-day not including radiation because of two reasons: the first is that we have only temperature and precipitation data as input; the second is that currently we are interested in representing the cumulative discharge volume and the general seasonal pattern of discharge. It is known that degree day with radiation, both potential or measured, allows to better reproduce daily fluctuation in discharge, as it can be seen in Hock, 1999; Hock, 2003; Pellicciotti et al., 2005 by the greater values of the efficiency index; but as stated in Hock, 1999 the introduction of radiation does not improve anymore simulated cumulative discharge volume.

For the iced-covered catchment part, the liquid fraction of ice water equivalent is supposed to not infiltrate into the soil, but it flows through the ice following the river network with a linear reservoir routing scheme, until it reaches a cell not cover by snow or ice. At this point, the melted water is added to the liquid precipitation of that cell.

The model has one parameter to calibrate: the melt coefficient, $\mathrm{C}_{\text {ice. }}$. As for the snow model, the parameter of the model does not vary in space and time, but is fixed for the catchment for the whole simulation period.

\section{Glaciers initial conditions}

Initial conditions require two information: the glaciers area and the ice thickness in each cell.For the first request, the GLIMS project (www.glims.org) allows to obtain the most recent mapping of glaciers around the world.

The best way to have information about glaciers thickness is to do direct measurements, as radio-echo soundings, but this kind of measures is very difficult and unusual over large areas. In literature, several approaches to estimate glaciers thickness have been developed. One method use volume-area scale relations for glaciers (Chen and Ohmura, 1990); this allows to obtain the mean ice thickness over the entire glacier. Other methods involve principles of ice flow mechanics and require knowledge of surface velocity field, as the one developed by Farinotti et al., 2009a, b; despite the accuracy of this method, such a physical modelling approach requires an onerous input data set and can only be applied to wellmonitored glacier system. Recently, Clarke et al., 2009 addressed the problem by developing an artificial neural networks approach to estimate subglacial topography using geometric information extracted from a DEM. They found interesting results in estimating glaciers volume, while glacier thickness has unavoidable errors. A shortcoming of this method is the computationally effort. Another approach is the one by Huss et al., 2008: they assumed that the glacier is near a steady-state configuration with respect to a known or estimated mass balance forcing; with this assumption, they calculate the balance ice flux that can be inverted to ice thickness using Glen's flow law. Another class of methods employs the perfect plasticity assumption coming from Nye, 1952 theory for the flow mechanics of an infinitely wide glacier (Wallinga and van de Wal, 1998; Aleynikov et al., 2002; Hoelzle et al., 2003; Li et al., 2012). This method ignores the longitudinal stress gradient. Li et al., 2012 tried to overcome this limitation by taking into account the width of the glacier cross section, so they modified the standard formulation suggested by Paterson (1970a, b). The results show that the method can give superior results compared to the standard method when accurate values of width are given to the model.

For this study, the Nye's theory revised by Aleynikov et al., 2002 has been used because it is simple, it does not involve onerous calculation and data request, but allows to maintain the raster-based approach, characterizing each iced cell with the correspondent ice thickness. The ice thickness is calculated with Equation (5), knowing the local slope $\alpha$, the average density of ice, $\rho$ (equal to $840 \mathrm{~kg} / \mathrm{m}^{3}$ ), the gravity acceleration, $g$, and the maximum possible shear stress, $\tau_{\mathrm{P}}$ (equal to $0.10 \mathrm{MPa}$ ).

$$
h=\frac{\tau_{P}}{\rho \cdot g \cdot \sin \alpha}
$$

However, this formulation is valid only for plane areas with $l>5 h$; for the remaining areas, where approximation of a glacier by a plane-parallel plate is inappropriate, the maximum thickness of the glacier would be higher in comparison with calculation made with Equation (5). To be correct, the equation should be modified by inserting a coefficient depending on the glacier width, $b$ :

$$
h=\left(1+\frac{h}{b}\right) \frac{\tau_{P}}{\rho \cdot g \cdot \sin \alpha}
$$

where $h$ represents the results of the calculation according to Equation (5).The first important step to do to initialize glacier model was so to calculate the amount of volume of glacier on the basin. The reference year for this calculation was 1999, because the GLIMS shapefile with glaciers extension is referred to that year. We have calculated the ice thickness in each cell of the basin with Equation (5), but aware of possible underestimation of total amount of glaciers in the basin, we compared our volume of glacier with the one computed by Farinotti (Farinotti et al., 2009a, b), referred to 1999, too. We found that the volume we computed using Equation (5) was $40 \%$ underestimated. 
Hence, we applied a correction factor to initial ice thickness map that provide a total amount of glacier equal to $63 \mathrm{~km}^{3}$.

Equation (6) involving glaciers width has not been used for two reasons: first, GLIMS shapefile does not include information about glacier width, length and neither elevation; second, more than 300 of the 550 glaciers of the basin have an area smaller than DEM cell resolution, so calculating glaciers width would lead to inaccurate results: as stated in $\mathrm{Li}$ et al., 2012, using ambiguous values of glacier width can lead to worst results.

\section{MODEL CALIBRATION AND VALIDATION}

The calibration of FEST-EWB model is focused on the calibration and validation of the snow accumulation model and on the glacier melt model. For both models, we have used a trial-and-error approach. The procedure is different for the two sub-models depending on the data available.

No any further calibration on soil parameters has been done.

The methodology is described in details in the following subsections.

\section{Calibration and validation of the snow accumulation model}

The calibration of the snow accumulation temperature parameters $T_{L O W}$ and $T_{U P}$ of Equation (3) is based on the comparison of simulated snow cover percentage with the one retrieved from satellite images.

The parameters of the snow melt model are assumed to be, respectively, $C_{m \text {,snow }}$ equal to $4.32 \mathrm{~mm} \mathrm{~d}^{-1}{ }^{\circ} \mathrm{C}^{-1}$ and $T_{b \text {,snow }}$ equal to $0^{\circ} \mathrm{C}$ (Corbari et al., 2009). The parameter of the linear reservoir for the flow routing is fixed at $83 \mathrm{~h}$ (Corbari et al., 2009).

The threshold temperature values depend on local meteorological conditions, so a wide range of values has been used in literature: from $-1{ }^{\circ} \mathrm{C}$ to $3{ }^{\circ} \mathrm{C}$ (Tarboton and Luce, 1996), from $-1{ }^{\circ} \mathrm{C}$ to $7{ }^{\circ} \mathrm{C}$ (Braun, 1991), from $0.5^{\circ} \mathrm{C}$ to $1^{\circ} \mathrm{C}$ (US Army Corps of Engineers, 1956).

The available images data set of snow cover have been subdivided in two part, from February 2000 to December 2004 for calibration and the remaining maps, till December 2008, for validation.

The period of calibration starts October 1 and ends May 2004; the months from January to September 2000 are not taken into account because they were considered as initialization period of the model. Furthermore, maps from June to September are not used, to avoid errors due to incorrect classification of iced pixel as snow covered and MODIS maps with a percentage of clouds cover greater than $30 \%$ have been removed because the percentage of snow cover is deeply altered by the presence of clouds. Notice in Figure 3 and in Table I how, removing the satellite maps with a great coverage of clouds, the trend and the values of indices (Equation (7), (8) and (9)) improve.

Remembering that MODIS maps have a temporal resolution of 8 days, in the entire period of calibration, the available number of maps was 109, 124 maps in the period of validation.

The calibration has been done with the 'trial and error' approach, in which the parameters have been varied in the range $0{ }^{\circ} \mathrm{C} \div-1{ }^{\circ} \mathrm{C}$. To compare simulated snow cover maps with the one from satellite, it is necessary to process the simulated map of snow depth in a binary way: the pixel with snow depth greater than zero are classified as 'snow', when snow depth is zero, they are marked as 'no snow'. In such a way, it was possible to calculate the percentage of snow cover for each day and compare it with the one obtainable by satellite maps.

The choice of the values of parameters is based on the calculation of three objective indices: the root mean squared error (RMSE), Equation (7), the mean absolute error (MAE), Equation (8), and the Nash and Sutcliffe (Nash, 1970) efficiency index, Equation (9).

$$
\begin{gathered}
R M S E=\sqrt{\frac{\sum_{i=1}^{n}\left(x_{1, i}-x_{2, i}\right)^{2}}{n}} \\
M A E=\frac{1}{n} \sum_{i=1}^{n}\left|x_{1, i}-x_{2, i}\right|
\end{gathered}
$$

Table I. Performance indexes calculated with and without clouds cover filter

\begin{tabular}{cccccc}
\hline \multicolumn{2}{c}{ Without clouds cover filter } & \multicolumn{3}{c}{ With clouds cover filter of 30\% } \\
\hline RMSE & MAE & NASH AND & RMSE & MAE & NASH AND \\
& & SUTCLIFFE & & & SUTCLIFFE \\
17.99 & 12.31 & 0.27 & 11.85 & 9.15 & 0.54 \\
\hline
\end{tabular}

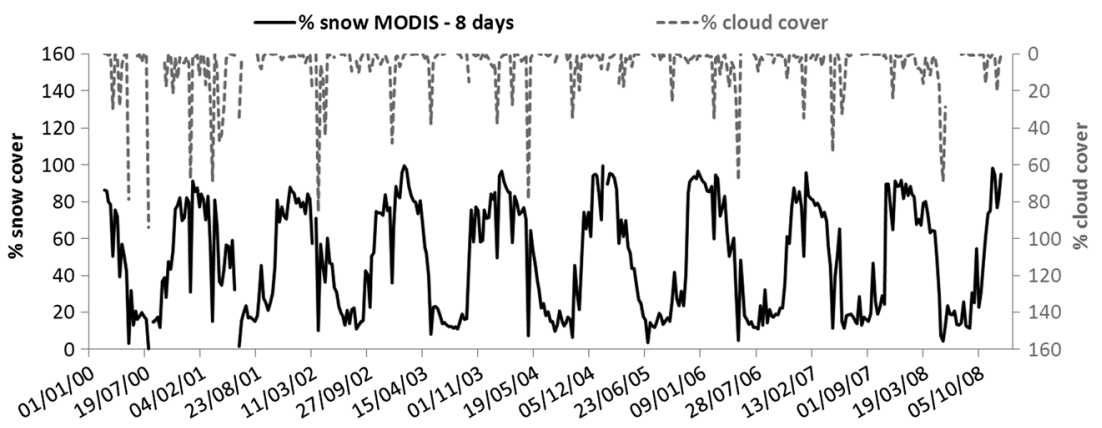

Figure 3. Trends of snow coverage and cloud coverage on Rhone basin from 2000 to 2008 


$$
R^{2}=1-\frac{\sum_{i=1}^{n}\left(x_{1, i}-x_{2, i}\right)^{2}}{\sum_{i=1}^{n}\left(x_{1, i}-x_{1, i}^{-}\right)^{2}}
$$

where $x_{1, i}$ is the observed percentage of snow cover, $x_{2, i}$ is the simulated percentage of snow cover and $n$ is the total number of compared maps.

\section{Calibration and validation of the glacier model}

Typically, degree-day melt model are calibrated according to measured mass balance gradients (Hock, 2003). On the other hand, when melt rate are not available, the calibration process is based on comparison between simulated and observed discharge (Klok et al., 2001; Verbunt et al., 2003).

We decided to calibrate the glacier melt model using the hourly discharge recorded at the gauging station of Blatten Naters (Figure 4). The choice of this sub-basin, the Massa basin, was due to several factors. The discharge gauging station is upstream of the Gebidem dam, so measured discharge is not influenced by the presence of the dam; it is for the $62 \%$ covered by glaciers, and all the soil is classified as rock, firn or glacier. With this premises, we could assume that the discharge in the sub-basin is mainly due to snow and glacier melt and that soil parameters do not affect consistently the flow.

The calibration was done by comparing measured and simulated discharge using the Nash-Sutcliffe efficiency criterion (Nash, 1970), $\mathrm{R}^{2}$ and $\mathrm{R}_{\log }^{2}$, Equation (10) and Equation (11), computed, respectively, for the absolute and the logarithm value of hourly discharge.

$$
\begin{gathered}
R^{2}=1-\frac{\sum_{i=1}^{n}\left(Q_{i, o b s}-Q_{i, s i m}\right)^{2}}{\sum_{i=1}^{n}\left(Q_{i, o b s}-Q_{i, o b s}^{-}\right)^{2}} \\
R_{\log }^{2}=1-\frac{\sum_{i=1}^{n}\left[\log \left(Q_{i, o b s}\right)-\log \left(Q_{i, s i m}\right)\right]^{2}}{\sum_{i=1}^{n}\left[\log \left(Q_{i, o b s}\right)-\log \left(Q_{i, o b s}^{-}\right)\right]^{2}}
\end{gathered}
$$

It is well known in literature (Hock, 1999) that classical temperature-index models have two major disadvantages: the restricted temporal resolution and the small accuracy in modeling spatial variability of melt rates. Daily time resolution, as the one used in this study, is insufficient to capture peak discharges and the pronounced diurnal cycle of glaciated covered basins. Concerning the spatial variability, degree day factors are usually assumed invariant in space, although some models use different degree day for different aspect classes. Nevertheless, degree day factors are subjected to small-scale variations, especially in high mountain regions; this is due to the effects of the surrounding topography and in particular to shading, aspect and slope angle that exert a strong control on global radiation. However, since our aim was to reproduce fairly the average melt rates, the classical degree-day approach is considered a good index, not only for the sub-basin, but also for the whole basin studied. In fact, we verified that the distribution of altitude of the Rhone basin is comparable to the one of the Massa basin, Figure 5, and so, given that melt rate depends indirectly from altitude, we extended the calibrated $C_{i c e}$ for Massa basin to the whole Rhone basin.

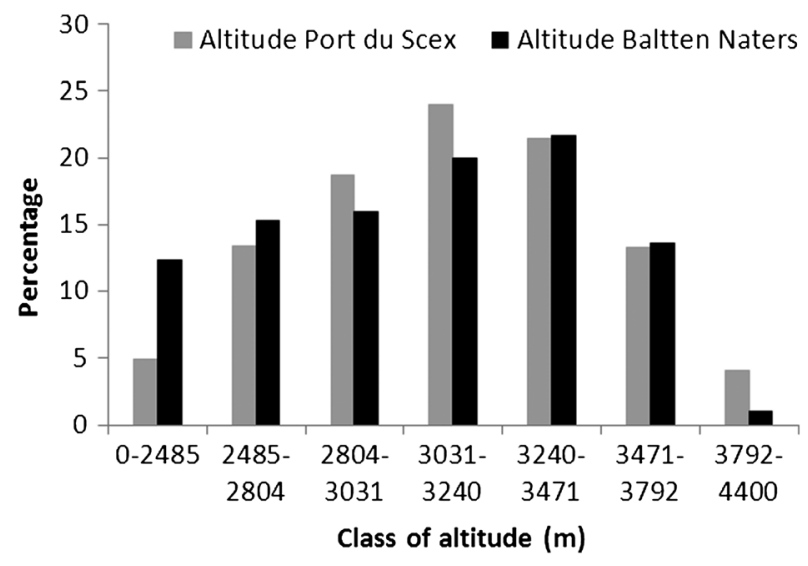

Figure 5. Comparison of the distribution of altitude of Rhone basin and of Massa basin

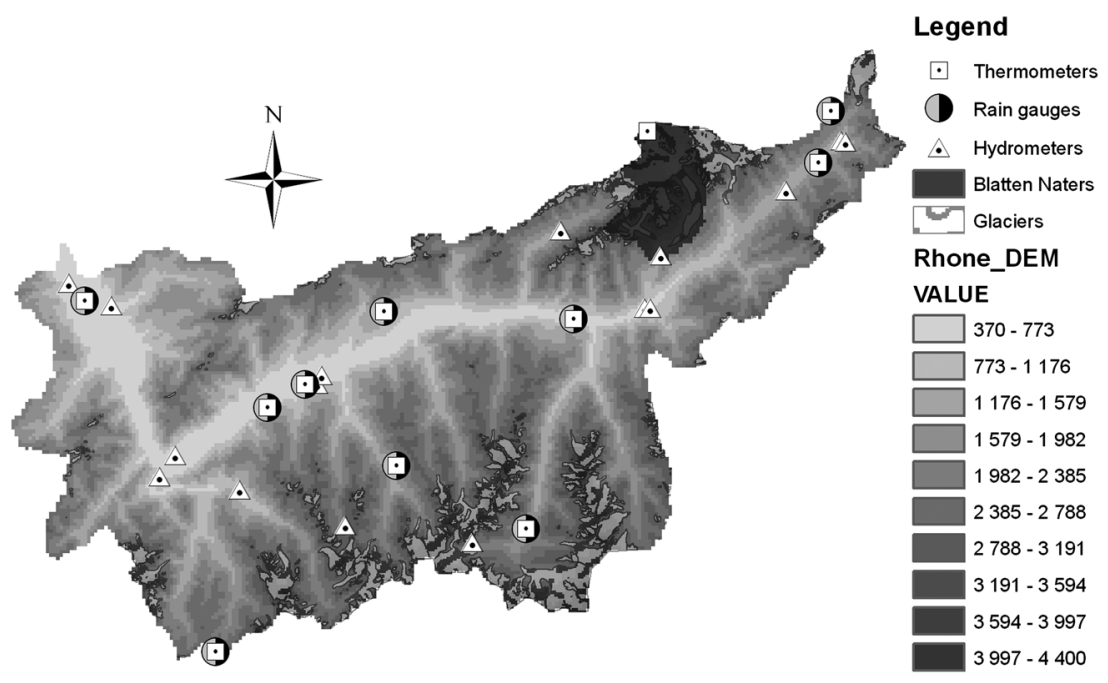

Figure 4. In black, the sub-basin of Blatten Naters is shown 
This assumption is verified by calculating the ice volume percentage reduction, as reported in Results and Discussion sub-section occurred in summer 2003, which according to Farinotti (Farinotti et al., 2009a, b) has been in the range $3 \%-4 \%$ for all the Swiss glaciers.

The other parameters of the model were assumed constant; their values are reported in Table II.

\section{RESULTS AND DISCUSSION}

\section{Snow accumulation model}

Results of calibration and validation of the snow accumulation model are summarized in Table III, which shows the calibrated values of $T_{L O W}$ and $T_{U P}$ with the performance indexes for calibration and validation period, and in Figure 6, that illustrates the comparison between simulated snow coverage and observed snow coverage. The model perform well both in accumulation and melting period, but globally, FEST-WB overestimation of snow coverage is about $9 \%$. The months in which the major differences are registered, are from June to September; this is probably due to the fact that snowfalls occurring in summer are of low intensity and so hardly representable.

None of the indexes used for calibration takes into account the spatial distribution of snow. At this purpose, we wanted to verify the spatial distribution of snow on the

Table II. Values of the parameters of glacier model

Parameter Value

Threshold temperature for ice melt, $T_{b, i c e}$

Time constant for the linear reservoir, $\tau$

$0 \mathrm{C}^{\circ}$

$12 \mathrm{~h}$

Table III. Values of the calibrated parameters for snow accumulation model and performance indexes

\begin{tabular}{lcc}
\hline \multicolumn{3}{c}{$\mathrm{T}_{\text {LOW }}=-1{ }^{\circ} \mathrm{C} \mathrm{T}_{\mathrm{UP}}=-1{ }^{\circ} \mathrm{C}$} \\
\hline & Calibration & Validation \\
RMSE & 11.85 & 14.11 \\
MAE & 9.15 & 10.84 \\
NASH AND SUTCLIFFE & 0.54 & 0.64 \\
\hline
\end{tabular}

basin by comparing simulated and observed maps. Our objective was thus to demonstrate that it is possible to calibrate the parameters without the evaluation of spatial distribution, but only comparing the percentage of snow cover. We chose maps in three periods: accumulation, winter and melt period, and we compared them graphically, as shown in Figure 7 . In each of the three periods, we can see a good agreement also from spatial distribution point of view, validating the hypothesis that it is possible to calibrate the model only comparing the percentage of snow coverage.

\section{Glacier melt model}

For calibration and validation of glacier melt model, two non-overlapping periods have been taken: from 1999 to 2004 for calibration and from 2004 to 2008 for validation.

In Table IV, the results of the performance indexes for the value of $C_{i c e}$ found after calibration are summarized.The values of $\mathrm{R}^{2}$ and $\mathrm{R}_{\log }^{2}$ highlight that the model perform quite well. As shown in Figure 8c, the average trend of discharge is well reproduced, while the absence of the typical oscillatory behaviour of melted water is mostly due to the melt model, without radiation, used in this study, because as known in literature, radiation is the principal reason of great oscillation in melt water (Hock, 1999; Hock, 2003; Verbunt et al., 2003). It is evident how the discharge is mostly influenced by snow and glacier melt; in fact, in winter season, the discharge of Massa river is close to zero, and it starts to increase with late spring season in which temperatures come to be greater than zero. This is evident in Figure 8: it represents simulated and observed discharge in relation with temperature and precipitation. It is clear how discharge is positively related to temperature, and how most of precipitation occurs when temperature is lower than zero degrees, and thus accumulates as snow.

Figure 9 shows the mean monthly water balance computed with data from 1999 to 2008 . We can notice how precipitation is uniformly distributed during all months of the year, but about $65 \%$ of the total amount is accumulated as snow because of lower temperature registered from May to October. The highest values of runoff are from June to September, when snow and glacier melt increase. It is striking from the values in Figure 9 how

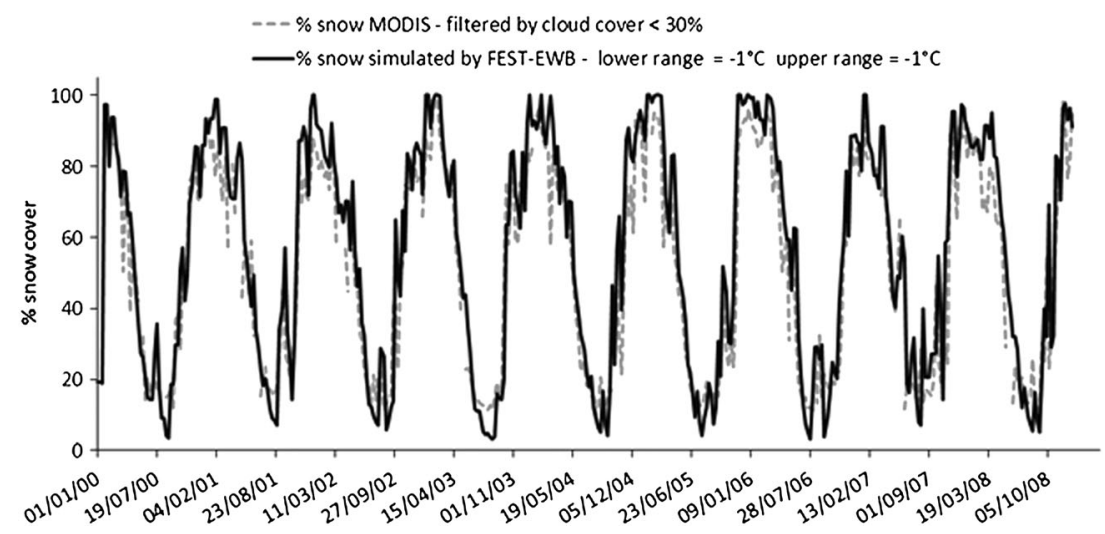

Figure 6. Comparison between simulated and observed snow coverage from 2000 to 2008 

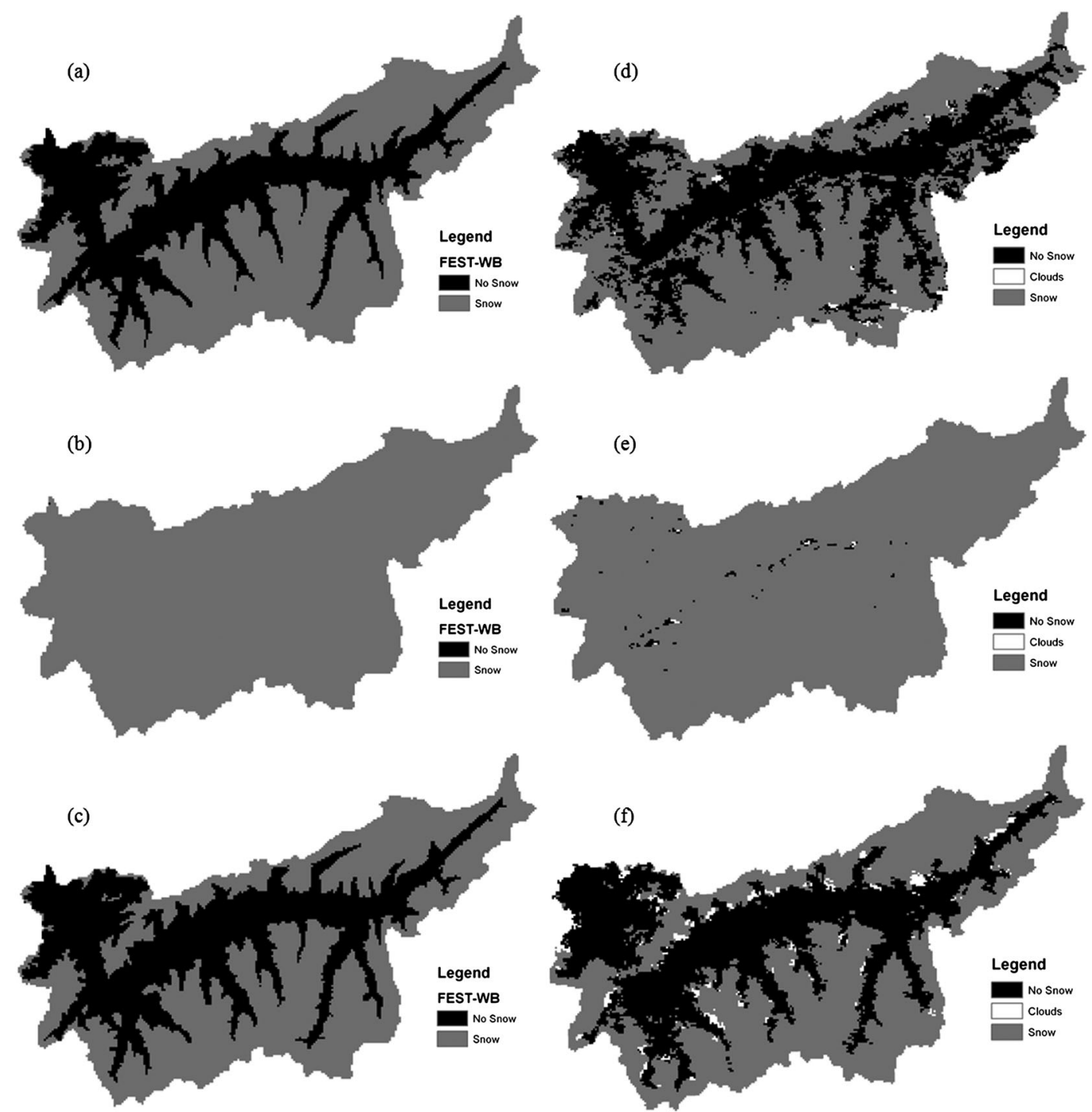

Figure 7. Comparison between FEST-WB (a, b, c) and MODIS (d, e, f) snow distribution maps. Maps (a) and (d) are referred to 16/10/2003, maps (b) and (e) are referred to 10/02/2003, maps (c) and (f) are referred to 09/05/2001

Table IV. Calibrated value for ice melt model and efficiency indexes values

\begin{tabular}{lcc}
\hline & $C_{\text {ice }}=7.01 * 10^{-8} \mathrm{~m} / \mathrm{s} \cdot{ }^{\circ} \mathrm{C}$ \\
\hline & Calibration & Validation \\
$\mathrm{R}^{2}$ & 0.891 & 0.855 \\
$\mathrm{R}_{\log }^{2}$ & 0.825 & 0.891 \\
\hline
\end{tabular}

the great part of the discharge is due to snow and glacier melt during summer season.

Despite the parsimonious structure of the model, the average trend is well reproduced, as shown in Figure 10, which represent the average daily observed and simulated discharge, computed from 1999 to 2008. The diurnal and seasonal fluctuations in observed discharge caused by fluctuations in air temperature and incoming global radiation are evident; the simulated discharge follows well the seasonal fluctuation, as involved by the use of a simple degree day, which can give good information about the average melt rate (Hock, 1999; Klok et al., 2001; Hock, 2003).
If we look at cumulated volume computed from 1999 to 2008, represented in Figure 11, we observe a very good agreement: the percentage difference is $4.3 \%$. Hence, the model is capable to reproduce in a good manner the volume of water melted during a season.

\section{Model performance on the Rhone basin}

Once calibrated, the glacier dynamic model of the Blatten Naters sub-basin, we wanted to verify its behaviour on the whole basin.

In Figure 12, observed and simulated discharges, with and without glaciers dynamic, are presented: it is evident the great contribution of glacier melt, so that it would be impossible to not consider it.

The performance of the model at Port du Scex is verified by calculating the reduction percentage of ice in summer 2003 and comparing it with the one retrieved by Farinotti (Farinotti et al., 2009a, b). The 2003 summer was particularly extreme: the mean summer temperature was of $3{ }^{\circ} \mathrm{C}$ greater than the seasonal mean, precipitation were of $31 \%$ lower than the season mean, so in this year, summer 


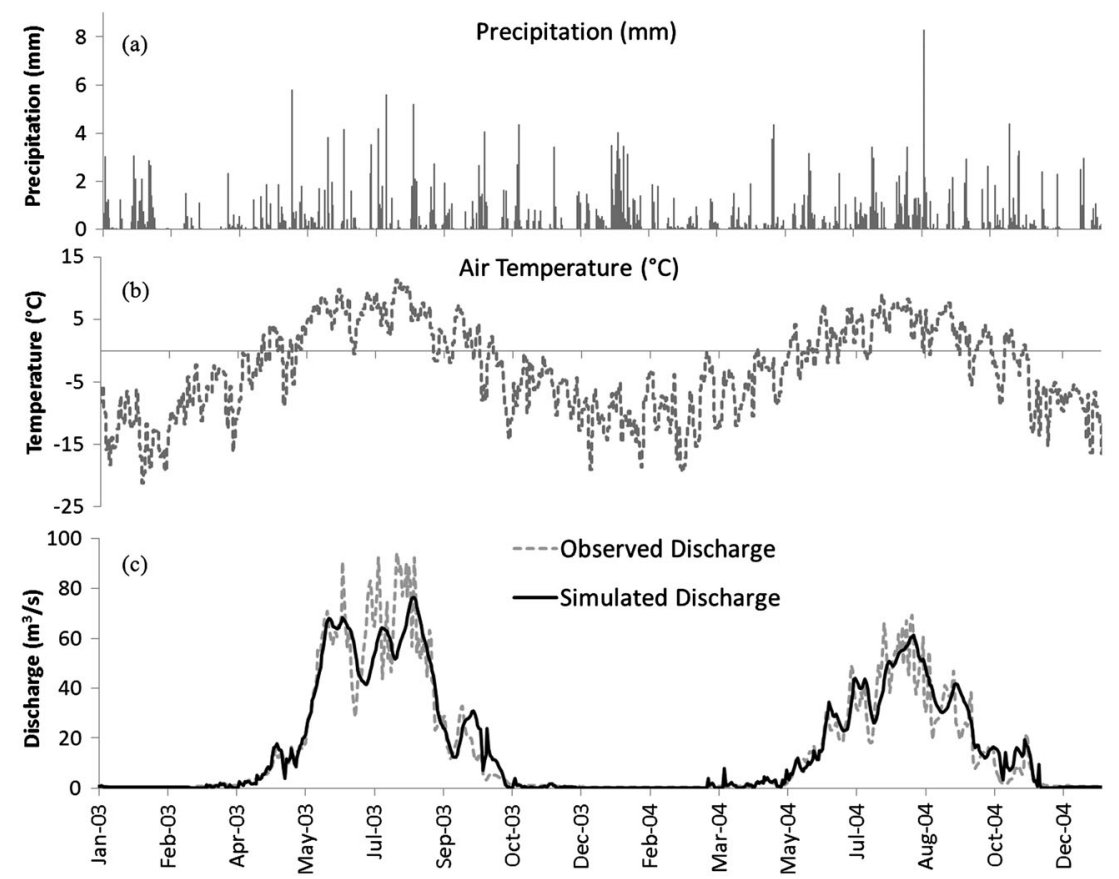

Figure 8. There are presented for years 2003 and 2004: (a) precipitation, (b) air temperature, (c) comparison between simulated and measured daily discharges

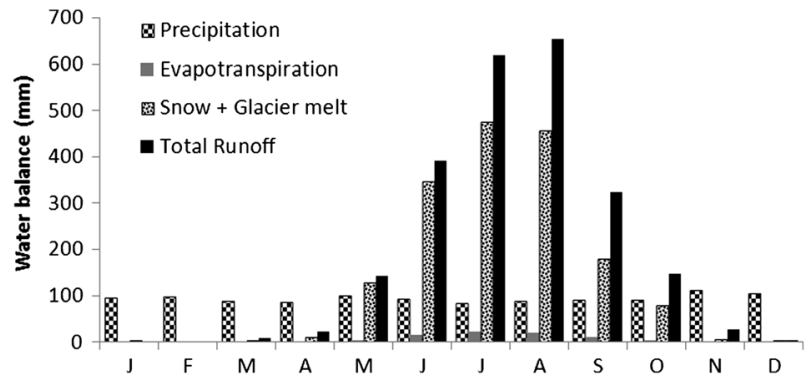

Figure 9. Mean annual water balance computed for years from 1999 to 2008

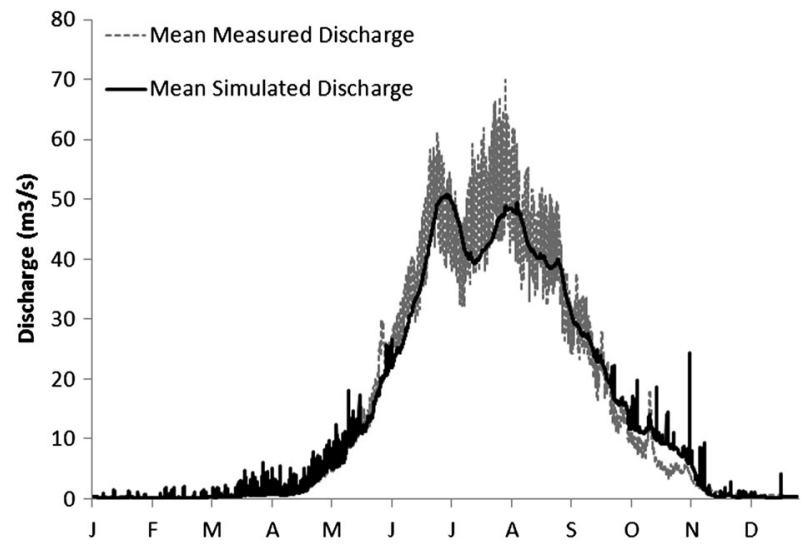

Figure 10. Comparison between annual simulated and observed mean daily discharges

discharge was largely influenced by glaciers melt, almost in all the Alps. This is the reason why we assumed that the percentage reduction of ice volume in 2003 computed by Farinotti (Farinotti et al., 2009a, b), equal to 3.5\%, could be extended to the basin in exam.

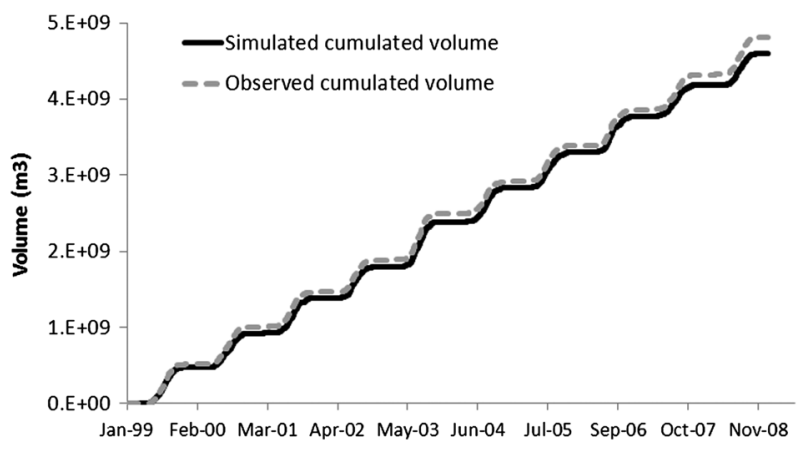

Figure 11. Evolution of the simulated and measured cumulated volumes at Blatten Naters gauging station from 1999 to 2008

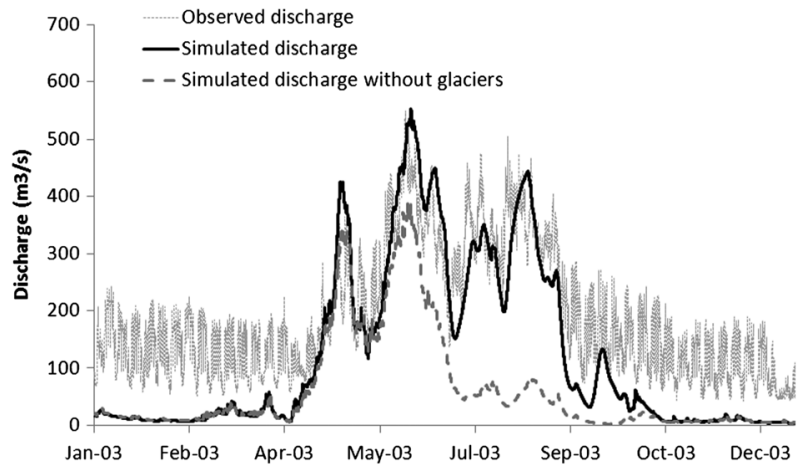

Figure 12. Comparison of the measured discharge with the simulated discharge with and without glacier melt contribution at Port du Scex gauging station

With the calibrated $C_{i c e}$, we obtained that in 2003 summer, the ice volume diminished by $2.9 \%$ with respect to the starting volume of ice in 1999.

The difference in the percentage can probably be attributed to the different melt model used in the 
studies: the one implemented by Farinotti (Farinotti et al., 2009a, b) has certainly a strong physical basis and is suitable to compute glaciers changes in details. The other source of uncertainty is the starting volume: the one computed by Farinoti (Farinotti et al., 2009a, b) for all Swiss glaciers, from which we deduced the starting volume for Rhone catchment, has an uncertainty of $\pm 9 \mathrm{~km}^{3}$. Propagating this uncertainty in our basin, we found that the percentage reduction of glacier volume can vary from $2.5 \%$ up to $3.3 \%$.

In Figure 13, summer hydrological balance, referred to Port du Scex catchment, is reported. The discharge and the precipitation are measured, snow and glaciers melt are calculated by the FEST-WB. It is easy to notice how the volume of water coming from glaciers melt is an essential contribution to the discharge volume, also in such a big basin as the one in exam. We estimated a contribution of glacier melt in summer runoff equal to $40 \%$ at Port du Scex for the years 1999-2008; this percentage increase up to $65 \%$ for the extreme summer of 2003.

Finally, results regarding glaciers thickness are shown. Since this is not a specific study on one glacier, but they are all treated with the same parameters, the variation of ice thickness averaged on the whole basin is presented, so considering all the glaciers present in the Rhone catchment. Figure 14 represent the average mass balance of all glaciers and the mean summer temperature from 1999 to 2008. As it can be noticed, the mass balance is completely in agreement with mean summer temperature, as the glacier model used implies. The mean annual mass balance for the nine years of simulation is $-1.5 \mathrm{~m}$. The mean trend of mass balance is comparable with the one reported in Farinotti et al., $2009 \mathrm{~b}$, for another set of Swiss glaciers, in particular the great loss of ice in 2003.

In Figure 15 is reported the distribution of ice thicknesses, calculated as explained in section 3.3, on the basin: for each class of ice thickness is reported the correspondent number of cells covered by ice in that class; the grey bars are the distribution referred to 1999, while the black bars are the one referred to 2008. There is a decrement in the number of cells with high ice thickness, while in the class with the smallest values, there is a little increase; the maximum ice thickness varies from $602 \mathrm{~m}$ in 1999 to $599 \mathrm{~m}$ in 2008 .

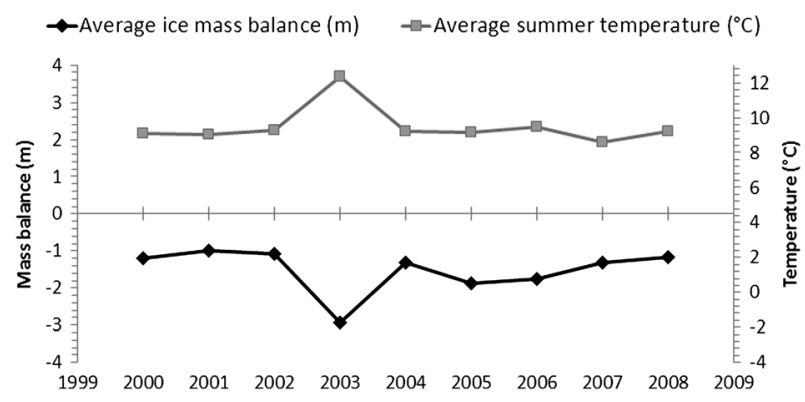

Figure 14. Average ice mass balance of all Rhone glaciers and mean summer temperature from 1999 to 2008

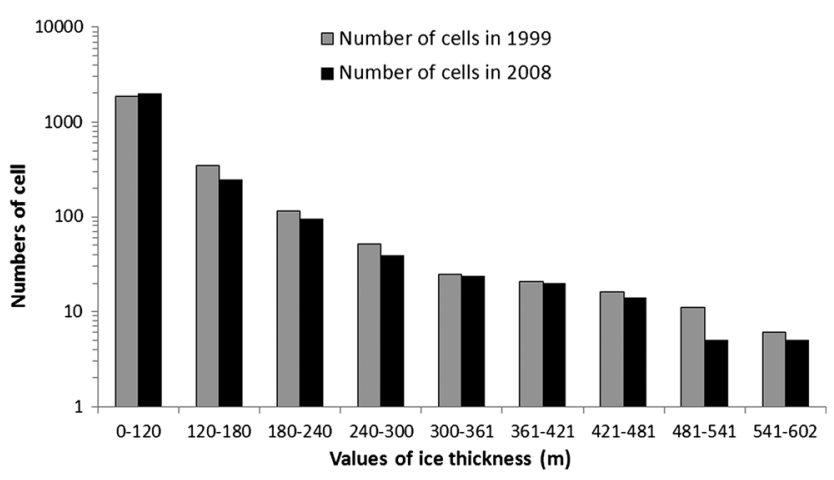

Figure 15. Distribution of ice thicknesses on the Rhone basin in 1999 and in 2008

\section{CONCLUSION}

A new module to simulate glaciers has been introduced in FEST-WB distributed hydrological model. The introduced glacier model has a simple structure and is built to be suitable for data input owned and to be fairly introduced in the rest of the hydrological model. Concerning data input, the model requires only precipitation and temperature as meteorological input and glaciers initial condition. The hydrological model requires a raster-based approach with a spatial resolution of cells of $500 \times 500 \mathrm{~m}$; this is a key point since it allows to evaluate the evolution of ice thickness in each glaciated cell and of glaciers area in the whole basin. The model is also able to well reproduce the water contribution coming from glaciers melt in summer also in a big catchment, in which glacier melt is not negligible. In fact, the strength of this study is that the model was applied to a large catchment, the Swiss Rhone with an area of $5300 \mathrm{~km}^{2}$. In such an Alpine basin, snow and glaciers

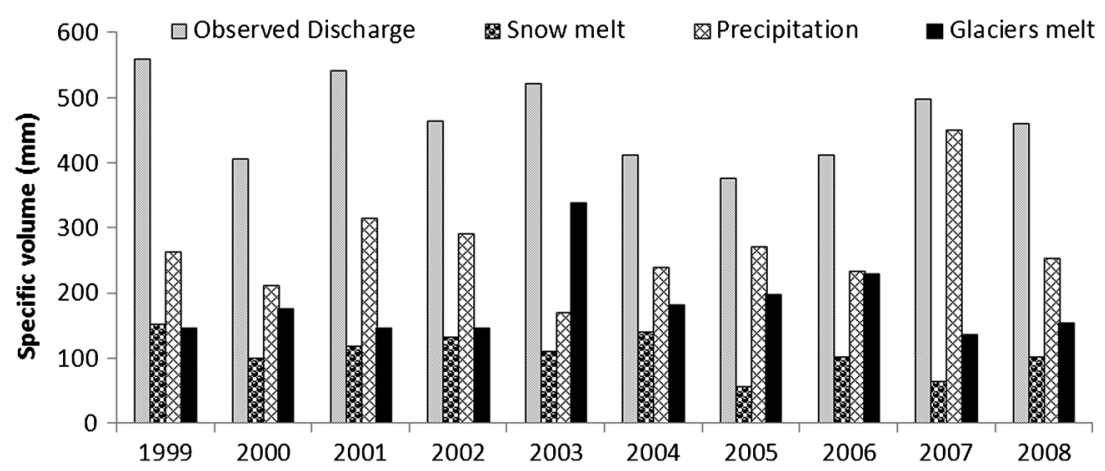

Figure 13. Summer hydrological balance referred at Port du Scex catchment: measured discharge and interpolated precipitation and simulated snow and glacier melt 
play a fundamental role in the hydrological regime, and the calibration of their model is of decisive importance in the generation of runoff. On the contrary, uncertainties in the precipitation in high altitude zones, due to lack of measurements, represent a great problem.

The calibration and validation of the snow accumulation model and of the glacier melt model were treated, based on multiple data sets: satellite snow cover maps and observed discharge.

The snow accumulation model was calibrated and validated by comparing simulated percentage of snow coverage with the one retrieved by satellite. The results showed good performance also from the point of view of spatial distribution of snow on the basin. This is an interesting point: with the only analysis of snow cover percentage, it is possible to obtain good performance also on spatial distribution.

The glacier melt model was first calibrated and validated by comparing observed and simulated discharge in the subbasin of Blatten Naters. Despite the simplicity of the model, the results showed a good performance considering seasonal behaviour $\left(\mathrm{R}^{2}=0.877\right.$ and $\left.\mathrm{R}_{\log }^{2}=0.851\right)$ and considering the annual volume of water (the mean difference in annual cumulated volume is $4.3 \%$ ), due for $67 \%$ to glacier melt in summer season.

We evaluated the performance of the calibrated glacier melt model over the entire basin. Since the $40 \%$ of discharge in summer comes from glacier melt, it was necessary to take into account this big source of water. By using the calibrated glacier model, we validated the performance of the model by comparing the ice volume percentage reduction for the extreme summer 2003 retrieved by the model with the one computed in the study carried out by Farinotti (Farinotti et al., 2009a, b): considering the uncertainty due to initial volume of ice in 1999, the range in which vary our computed percentage was $2.5 \%-3 \%$, in good agreement with the one by Farinotti (Farinotti et al., 2009a, b).

In spite of the parsimonious structure and the crude assumption of having one average glacier melt coefficient for all glaciers, the introduced model allowed to obtain interesting results because it permitted to take into account the volume of water coming from glaciers melt, and this will be surely a key point in the evaluation of the changes in hydrological regime subjected to a future climate scenario.

\section{ACKNOWLEDGEMENTS}

The work was supported in the framework of the ACQWA EU/FP7 project (grant number 212250) 'Assessing Climate impacts on the Quantity and quality of Water'. The authors thank MeteoSwiss for providing meteorological data. This work has been also supported by Regione Lombardia and CILEA Consortium through a LISA Initiative (Laboratory for Interdisciplinary Advanced Simulation) 2010 grant [link: http://lisa.cilea.it]. This work was partially developed in collaboration with LTHE, CNRS, Université Joseph Fourier, Grenoble, France.

\section{REFERENCES}

Aleynikov AA, Popovnin VV, Voytkovskiy KF, Zolotaryov YA. 2002. Indirect estimation of the Djankuat Glacier volume based on surface topography. Nordic Hydrology 33(1): 95-110.

Braun LN 1991. Modelling the snow water equivalent in the mountain environment. IAHS Publication: 205: 3-17.

Chen J, Ohmura A. 1990. Estimation of Alpine glacier water resources and their change since the 1870 s. Hydrology in Mountain Regions. I Hydrological Measurement; the Water Cycle. Proceedings of two Lausanne Symposia. IAHS Publication. 193: 127-135.

Clarke GK, Berthier E, Schoof CG, Jarosh AH. 2009. Neural networks applied to estimating subglacial topography and glacier volume. Journal of Climate 22: 2146-2160

Corbari C, Ravazzani G, Martinelli J, Mancini M. 2009. Elevation based correction of snow coverage retrieved from satellite images to improve model calibration. Hydrology and Earth System Sciences 13: 639-649.

Corbari C, Ravazzani G, Mancini M. 2011. A distributed thermodynamic model for energy and mass balance computation: FEST-EWB. Hydrological Processes 25(9): 1443-1452. DOI: 10.1002/hyp.7910.

Farinotti D, Huss M, Bauder A, Funk M, Truffer M. 2009a. A method to estimate the ice volume and ice-thickness distribution of alpine glaciers. Journal of Glaciology 55(191): 422-430

Farinotti D, Huss M, Bauder A, Funk M. 2009b. An estimate of the glacier ice volume in the Swiss Alps. Global and Planetary Change 68: 225-231

Finger D, Pellicciotti F, Konz M, Rimkus S, Burlando P. 2011. The value of glacier mass balance, satellite snow cover images, and hourly discharge for improving the performance of a physically based distributed hydrological model. Water Resources Research 47: W07519

Hargreaves GH, Samani ZA. 1985. Reference crop evapotranspiration from temperature. Applied Engineering in Agriculture 1: 96-99.

Hock R 1999. A distributed temperature-index ice- and snowmelt model including potential direct solar radiation. Journal of Glaciology 45(149): 101-111

Hock R 2003. Temperature index melt modelling in mountain areas. Journal of Hydrology 282: 104-115.

Hock R, Jansson P, Braun LN. 2005. Modelling the response of mountain glacier discharge to climate warming. Global Change and Mountain Region. 23: 243-252

Hoelzle M, Haeberli W, Dischl M, Peschke W. 2003. Secular glacier mass balance derived from cumulative glacier length changes. Global and Planetary Change 36: 295-306

Horton P, Schaefli B, Mezghani A, Hingray B, Musy A. 2006. Assessment of climate-change impacts on alpine discharge regimes with climate model uncertainty. Hydrological Processes 20: 2091-2109.

Huss M, Farinotti D, Bauder A, Funk M. 2008. Modelling runoff from highly glacierized alpine drainage basins in a changing climate. Hydrological Processes 22: 3888-3902.

Huss M 2011. Present and future cotribution of glacier storage change to runoff from macroscale drainage basins in Europe. Water Resources Research 47: W07511.

Johannesson T 1997. The response of two Iceland glaciers to climatic warming computed with a degreey day glacier mass-balance model coupled to a dynamic glacier model. Journal of Glaciology 43(143): 321-327.

Jost G, Moore RD, Menounos B, Wheate R. 2012. Quantifying the contribution of glacier runoff to streamflow in the upper Columbia River Basin, Canada. Hydrology and Earth System Science 16: 849-860.

Kaser G, Großhauser M, Marzeion B. 2010. Contribution potential of glaciers to water availability in different climate regimes. Proceedings of the National Academy of Sciences 107(47): 20223-20227.

Klok EJ, Jasper K, Roelofsma P, Gurtz J, Badoux A. 2001. Distributed hydrological modelling of a heavily glaciated Alpine river basin. Hydrological Sciences 46(4): 553-570.

Koboltschnig GR, Schöner W, Zappa M, Kroisleitner C, Holzmann H. 2008. Runoff modelling of the glacierized Alpine Upper Salzach basin (Austria): multi-criteria result validation. Hydrological Processes 22: 3950-3964.

Konz M, Seibert J. 2010. On the value of glacier mass balances for hydrological model calibration. Journal of Hydrology 385: 238-246.

Li H, Ng F, Li Z, Qin D, Cheng G. 2012. An extended "perfect plasticity" method for estimating ice thickness along the flow line of mountain glaciers. Journal of Geophysical Research 117: F01020

Milner AM, Brown LE, Hannah DM. 2009. Hydroecological response of river systems to shrinking glaciers. Hydrological Processes 23: 62-77.

Montaldo N, Ravazzani G, Mancini M. 2007. On the prediction of the Toce alpine basin floods with distributed hydrologic models. Hydrological Processes 21: 608-621. 
Nash J, Sutcliffe J V. 1970. River flow forecasting through the conceptual models, Part 1: a discussion of principles. Journal of Hydrology 10(3): 282-290.

Noldin I, Endrizzi S, Rigon R, Dall'Amico M. 2010. Sistema di drenaggio di un ghiacciaio alpino. Neve e Valanghe 69: 48-54.

Nye JF. 1952. The mechanics of glaciers flow. Journal of Glaciology 2(12): $82-93$

Oerlemans J 1997. A flowline model for Nigardsbreen, Norway: projection of future glacier length based on dynamic calibration with the historic record. Annals of Glaciology 24: 382-389.

Oerlemans J, Anderson B, Hubbard A, Huybrechts PH, Johannesson T, Knap WH, Schmeits M, Stroeven AP, van de Wal RSW, Wallinga J, Zuo Z. 1998. Modelling the response of glaciers to climate warming. Climate Dynamics 14: 267-274.

Parajka J, Blöschl G. 2006. Validation of MODIS snow cover images over Austria. Hydrology and Earth System Sciences 10: 679-689.

Paterson WSB. 1970a. The sliding velocity of Athabasca Glacier, Canada. Journal of Glaciology 9(55): 55-63.

Paterson WSB. 1970b. The application of ice physics to glacier studies in Glaciers: Proceedings of Workshop Seminar, 1970, 43-46. Can. Natl. Comm. For the Int. Hydrol. Decade, Ottawa.

Pellegrini M. 2011. Accuracy of modis snow cover images and calibration of hydrological model in Alpine river basins. Master thesis, Politecnico di Milano.

Pellicciotti F, Brock B, Strasser U, Burlando P, Funk M, Corripio J. 2005. An enhanced temperature -index melt model including the shortwave radiation balance: development and testing for Haut Glacier d'Arolla, Switzerland. Journal of Glaciology 51(175): 573-587

Ponce VM. 1989. Engineering Hydrology, Principles and Practices. Prentice Hall, Englewood Cliffs: New Jersey, USA; 260-261.

Rabuffetti D, Ravazzani G, Corbari C, Mancini M. 2008. Verification of operational Quantitative Discharge Forecast (QDF) for a regional warning system - the AMPHORE case studies in the upper Po River. Natural Hazards and Earth System 8: 161-173.

Ravazzani G, Mancini M, Giudici I, Amadio P. 2007. Effects of soil moisture parameterization on real-time flood forecasting system based on rainfall threshold, in Quantification and Reduction of Predictive Uncertainty for Sustainable Water Resources Management, Proc. Symposium HS2004 at IUGG2007, Perugia, IAHS Publication 313: 407-416.

Ravazzani G, Corbari C, Morella S, Gianoli P, Mancini M. 2012. Modified Hargreaves-Samani equation for the assessment of reference evapotranspiration in Alpine river basins. Journal of Irrigation and Drainage Engineering 138(7): 592-599.

Schaefli B, Hingray B, Niggli M, Musy A. 2005. A conceptual glaciohydrological model for high mountainous catchments. Hydrology and Earth System Sciences 9: 95-109.

Schaefli B, Huss M. 2011. Integrating point glacier mass balance observation into hydrologic model identification. Hydrology and Earth System Sciences 15: 1227-1241.

Soil Conservation Service, US. 1986. Urban hydrology for small watershed. Tech. Rel. no. 55. U.S. Department of Agriculture, Washington D.C.

Tarboton DG, Luce CH. 1996. Utah energy balance snow accumulation and melt model (UEB), computer model technical description and users guide. Logan: Utah Water Res. Lab.

US, Army Corps of Engineers. 1956. Snow Hydrology. US Army Corps of Engineers: North Pacific Division, Portland, Oregon.

Verbunt M, Gurtz J, Jasper K, Lang H, Warmerdam P, Zappa M. 2003. The hydrological role of snow and glaciers in alpine river basins and their distributed modelling. Journal of Hydrology 282: 36-55.

Verbunt M, Zappa M, Gurtz J, Kaufmann P. 2006. Verification of a coupled hydrometeorological modelling approach for alpine tributaries in the Rhine basin. Journal of Hydrology 324: 224-238.

Wallinga J, van de Wal SW. 1998. Sensitivity of Rhonegletscher, Switzerland, to climate change: experiments with a one-dimensional flowline model. Journal of Glaciology 44: 383-393. 